Journal Homepage: http://journal.umg.ac.id/index.php/tiaa

JIATAX 2 (1) 71-81 (2019)

\title{
Pengungkapan CSR tentang Kinerja Keuangan dan Lingkungan
}

\author{
Intan Novitasari ${ }^{1^{*}}$, Darti Djuharni ${ }^{2}$ \\ ${ }^{1,2}$ STIE Malangkuçeçwara Malang, Jl. Terusan Candi Kalasan, Malang, Indonesia
}

DOI: http://dx.doi.org/10.30587/jiatax.v2i1.1086

\section{Abstrak}

This research was conducted to test the effect of CSR on financial performance and add environmental variables as intervening. This type of research is Explonatory research using financial data published on the Indonesia Stock Exchange (IDX). The study was conducted on manufacturing companies in the consumer goods industry sector for three years, namely 2015, 2016, and 2017. From the number listed, they were selected according to the criteria determined to be used as research samples. The number of companies that met the criteria for further analysis was thirteen companies with observations over three years. The results of this study indicate that CSR significantly influences the company's financial performance, and environmental performance as an intervening variable significantly influences the company's financial performance.

Jenis Artiel: Empiris

Keywords: CSR; Financial performance; Environmental Performance; Explanatory Research; ROA

\section{Pengantar}

Tanggung jawab sosial atau yang sering disebut corporate social responsibility (CSR) merupakan kewajiban asasi perusahaan yang tidak boleh dihindari (Lako, 2011). Hal ini sebagai bentuk tanggung jawab yang ditimbulkan oleh aktivitas perusahaan. Seperti telah diatur oleh Undang-Undang Nomor 40 Tahun 2007 tentang Perseroan Terbatas (UUPT) yang mewajibkan perusahaan melakukan kegiatan berkaitan dengan sumber daya alam, harus melakukan tanggung jawab sosial kepada masyarakat. Undang-Undang tersebut menyebut CSR tidak lagi berkonsep sukarela akan tetapi masih ada perusahaan yang lalai dalam melaksanakan tuntutan tanggung jawab sosial karena dianggap sebagai beban.

Seorang investor lebih tertarik untuk melakukan investasi pada perusahaan yang memiliki citra yang baik di mata masyarakat sekitar, sehingga dianggap memiliki tingkat loyalitas konsumen yang tinggi. Hal ini senada dengan penelitian yang dilakukan oleh Rahmah and Iramani (2015) yang menjelaskan semakin banyak perusahaan melakukan

\footnotetext{
${ }^{*}$ Penulis yang sesuai:

E-mail: dartidjuharni@yahoo.com

Afiliasi: STIE Malangkuçeçwara Malang
} 
pertanggungjawaban sosial, semakin baik pula citra perusahaan dari pandangan masyarakat maupun investor, sehingga dapat disimpulkan bahwa program CSR termasuk bentuk investasi untuk keberlanjutan perusahaan seharusnya tidak dianggap sebagai beban, tetapi dijadikan sebagai salah satu cara untuk meningkatkan nilai perusahaan. Oleh karena itu, perusahaan dikatakan memiliki nilai yang baik apabila kinerja keuangannya juga baik.

Laporan keuangan menggambarkan kinerja suatu perusahaan karena didalamnya akan nampak kondisi dari keuangan tersebut. Hal ini senada dengan penelitian yang dilakukan oleh Rahmah and Iramani (2015)baik atau buruknya kinerja keuangan perusahaan dapat tercermin dari profit dan hutang yang dimilikinya. Untuk itu dibutuhkan analisis laporan keuangan agar dapat mengetahui keuangan perusahaan secara lebih detail.Analisis laporan keuangan perlu dilakukan secara sistematis dan terukur salah satunya dengan menggunakan rasio. Rasio keuangan sangat penting untuk melakukan analisis terhadap kinerja keuangan perusahaan (Bhernadha, Topowijono, \& Azizah, 2017). Rasio terbagi menjadi empat yaitu diantaranya rasio likuiditas, solvabilitas, aktivitas dan profitabilitas. Dalam penelitian ini penulis menggunakan rasio profitabilitas yang diproksikan dengan ROA dan ROE.Analisis laporan keuangan dibutuhkan terutama bagi investor yang ingin berinvestasi, sehingga meningkatkan serta mempertahankan kinerja keuangan merupakan suatu keharusan bagi perusahaan agar sahamnya tetap diminati investor.

Hasil penelitian sebelumnya mengungkapkan bahwa CSR berpengaruh secara signifikan terhadap ROA dan ROE (Setyono, 2016). Penelitian yang dilakukan oleh Rahmah and Iramani (2015) menunjukkan hasil bahwa CSR berpengaruh positif tidak signifikan terhadap ROA,sedangkan penelitian yang dilakukan oleh Parengkuan (2017) dan Pratiwi (2012) menunjukkan bahwa CSR tidak mempunyai pengaruh terhadap kinerja keuangan pada perusahaan, serta CSR tidak berpengaruh terhadap ROA.Penelitian-penelitian tersebut masih menunjukkan hasil yang berbeda, sehingga menarik dan perlu dilakukan penelitian lebih lanjut.

Berdasarkan hasil penelitian yang dilakukan oleh Rahmah and Iramani (2015) dengan judul pengaruh CSR terhadap kinerja keuangan perusahaan, maka peneliti akan melakukan penelitian tentang pengaruh CSR terhadap kinerja keuangan dengan menambah satu variabel yaitu kinerja lingkungan sebagai variabel moderasi. Penelitian ini dilakukan pada perusahaan pertambangan dari tahun 2015 sampai dengan 2017 yang terdaftar di BEI. Tujuan penelitian ini adalah untuk menguji pengaruh CSR terhadap kinerja keuangan perusahaan.

\section{Literature Review}

Corporate Social Responsibility atau CSR merupakan suatu keterbukaan mengenai aktivitas - aktivitas perusahaan khususnya yang berkaitan dengan kegiatan sosial, dimana tidak hanya informasi keuangan saja yang harus diungkapkan melainkan juga mengenai dampak yang ditimbulkan dari aktivitas perusahaan terutama bagi lingkungan hidup dan masyarakat sekitar (Candrayanthi \& Saputra, 2013).Gagasan CSR menurut (Ibrahim, Solikahan, \& Widyatama, 2015) juga menekankan bahwa tanggung jawab sosial perusahaan tidak hanya sekedar kegiatan ekonomi, yaitu mencari keuntungan untuk mempertahankan kelangsungan hidup perusahaan tetapi juga mementingkan tanggung jawab sosial dan lingkungan. Sedangkan menurut (Rosiana, Juliarsa, \& Maria M, 2013) CSR merupakan suatu bentuk tanggung jawab sosial untuk mengatasi masalah sosial dan lingkungan dari akibat aktivitas yang ditimbulkan oleh suatu perusahaan. Berdasarkan atas beberapa uraian tersebut dapat dikatakan bahwa CSR merupakan suatu bentuk nyata dari upaya perusahaan dalam bertanggung jawab atas dampak dari seluruh aktivitas perusahaan khususnya pada masyarakat dan lingkungan hidup. Sehingga perusahaan diharapkan dapat lebih memperhatikan kinerja lingkungannya.

Lingkungan merupakan segala sesuatu yang berada disekitar subyek manusia dengan segala aktivitasnya (Tjahjono, 2013). Sedangkan, kinerja lingkungan merupakan kinerja 
perusahaan yang berfokus pada kegiatan dalam melestarikan dan mengurangi dampak lingkungan yang timbul akibat aktivitas perusahaan (Setyono, 2016).Kementerian Lingkungan Hidup (KLH) menciptakan penilaian kinerja lingkungan dengan menggunakan peringkat PROPER (Program Penilaiian Peringkat Kinerja Perusahaan). PROPER menggunakan indikator warna untuk penilaian dan pemeringkatan, dimulai warna emas sebagai peringkat terbaik, selanjutnya yaitu warna hijau, biru, merah dan warna hitam untuk peringkat terburuk, dengan pemberian skor 1-5. Aspek dalam penilaian PROPER berdasarkan pada penilaian ketaatan perusahaan dalam melakukan pengendalian pencemaran air, udara, pengelolaan limbah bahan dan beracun (B3), kewajiban lain yang terkait dengan analisis mengenai dampak lingkungan (AMDAL), penetapan sistem Manajemen Lingkungan (SML), konservasi dan pemanfaatan sumber daya, serta kegiatan sosial perusahaan (fitriani, 2013). Sehingga Perusahaan bisa mendapatkan nilai tambah jika memperhatikan dengan baik kinerja lingkungan dan tanggung jawabnya.

Bentuk tanggungjawab perusahaan dapat dilalakukan dengan berbagai macam mulai dari memberikan beasiswa pendidikan, memperbaiki lingkungan, memberikan dana untuk membangun atau memperbaiki fasilitas umum, serta kegiatan yang mensejahterakan masyarakat khususnya yang berada pada sekitar perusahaan tersebut. Dengan melakukan pengungkapan CSR selain memberikan manfaat kepada para pemangku kepentingan perusahaan juga akan mendapat keuntungan, yaitu citra perusahaan akan dipandang baik bagi sehingga kinerja keuangan dapat meningkat.

Kinerja menurut Kamus Besar Bahasa Indonesia (2001) adalah sesuatu yang dicapai, prestasi yang diperlihatkan, kemampuan kerja (tentang peralatan). Kinerja keuangan merupakan suatu gambaran tentang upaya perusahaan dalam mencapai tujuannya yaitu menciptakan keuntungan serta meningkatkan nilai perusahaan (Setyono, 2016). Kinerja keuangan terbagi dalam empat rasio yaitu rasio likuiditas, solvabilitas, aktivitas dan profitabilitas. Analisis rasio keuangan merupakan salah satu metode yang umum yang digunakan dalam mengukur kinerja perusahaan pada bidang keuangan. Didalam perusahaan kinerja keuangan salah satu hal yang penting karena didalamnya tercermin bagaimana operasi jalannya perusahaan tersebut (Rahmah \& Iramani, 2015). Untuk menilai kinerja keuangan suatu perusahaan dapat dilihat melalui profit dan hutang yang dimiliki. Kinerja keuangan perusahaan merupakan salah satu hal yang diperhitungkan oleh seorang investor saat akan berinvestasi saham pada perusahaan(DJ, Artini, \& Suarjaya, 2012). Seorang investor tidak hanya tertarik pada perusahaan yang memiliki profit yang tinggi saja tetapi juga kepedulian terhadap stakeholder.

Stakeholder terdiri dari orang atau sekelompok orang yang bisa mempengaruhi atau dipengaruhi oleh berbagai kebijakan serta dalam pelaksanaan perusahaan (Gantino, 2016). Menurut teori stakeholder semua pemangku kepentingan mempunyai hak untuk memperoleh informasi mengenai aktivitas perusahaan dalam periode tertentu yang mampu mempengaruhi pengambilan suatu keputusan (Setyono, 2016). Perusahaan dalam mengatur stakeholdernya dapat menggunakan strategi aktif atau pasif (Purwanto, 2011).

Strategi aktif merupakan suatu strategi dimana perusahaan berusaha untuk mempengaruhi hubungan organisasinya dengan para pemangku kepentingannya yang dianggap berpengaruh. Sehingga strategi aktif secara tidak langsung dapat menentukan steakholder mana yang memiliki pengaruh yang besar terhadap alokasi ekonomi dalam perusahaan. Dengan memberikan perhatian yang besar terhadap stakeholder berarti ikut meningkatkan pula tingkat pengungkapan informasi serta kinerja sosiap perusahaan. Sedangkan perusahaan yang menggunakan strategi pasif tidak secara terus - menerus melakukan pengawasan terhadap stakeholder dan secara sengaja tidak berupaya mencari strategi yang terbaik, sehingga tingkat pengungkapan informasi dan kinerja sosial cenderung lebih rendah.Jika suatu perusahaan tidak 
memperhatikan para pemangku kepentingannya juga dapat mengakibatkan perusahaan kehilangan legitimasi.

Menurut teori legitimasi perusahaan berupaya secara terus - menerus dalam meyakinkan tentang seluruh kegiatan atau aktivitas perusahaannya masih sesuai dengan batas - batas normal masyarakat dimana perusahaan tersebut berada (Purwanto, 2011). Legitimasi adalah faktor strategi bagi perusahaan dalam rangka mengembangkan perusahaan ke depan, terutama terkait dengan upaya memposisikan di tengah lingkungan yang semakin maju. Legitimasi merupakan keadaan psikologis, keberpihakan orang dan suatu kelompok yang sangat peka terhadap gejala lingkungan sekitarnya baik fisik maupun non fisik (Rahmah \& Iramani, 2015). Dalam legitimasi dapat terjadi legitimacy gap yang disebabkan oleh beberapa faktor diantaranya yaitu, terdapat perubahan dalam kinerja perusahaan namun harapan masyarakat terhadap kinerja perusahaan tidak berubah, begitupun sebaliknya. Serta kinerja perusahaan dan harapan masyarakat berubah kearah yang sama tetapi waktunya berbeda.

Teori lain yang berkaitan dengan CSR yaitu teori agensi (agency theory). Menurut teori agensi, perusahaan dengan biaya kontrak dan pengawasan yang rendah cenderung melaporkan laba bersih yang rendah atau perusahaan tersebut akan mengeluarkan biaya untuk kepentingan manajemen (Gantino, 2016). Sebagai wujud pertanggungjawaban manajer sebagai pihak agen akan berupaya memenuhi semua kebutuhan pihak prinsipal, yaitu mengenai pengungkapan informasi tanggung jawab sosial perusahaan.

Pengembangan hipotesis dalam penelitian ini yaitu yang pertama pengaruh CSR terhadap kinerja keuangan perusahaan. Didalam suatu perusahaan kinerja keuangan adalah suatu hal yang penting karena mencerminkan bagaimana suatu perusahaan menjalankan aktivitas operasinya. Beberapa penelitian tentang CSR menunjukkan hasil yang berpengaruh salah satunya yaitu penelitian yang dilakukan oleh Bhernadha et al. (2017) yang menunjukkan bahwa CSR berpengaruh terhadap kinerja keuangan perusahaan. Dengan diterapkannya CSR diharapkan perusahaan akan memperoleh legitimasi dan dapat memaksimalkan keuangannya dalam jangka panjang. Berdasarkan informasi tersebut maka dapat dirumuskan hipotesis sebagai berikut:

H1 : CSR berpengaruh terhadap kinerja keuangan perusahaan.

Pengembangan hipotesis yang kedua yaitu pengaruh kinerja lingkungan sebagai variabel intervening terhadap kinerja keuangan perusahaan. Beberapa penelitian tentang kinerja lingkungan mempunyai pengaruh terhadap kinerja keuangan perusahaan. Setyono (2016) menemukan bahwa secara simultan kinerja lingkungan memiliki pengaruh terhadap kinerja keuangan perusahaan. Kepedulian perusahaan dalam bidang lingkungan dapat memberikan nilai tambah bagi perusahaan (Tjahjono, 2013). Dengan demikian diharapkan dari adanya kinerja lingkungan yang baik mampu memberikan kontribusi terhadap peningkatan kinerja keuangan perusahaan. Berdasarkan penjelasan tersebut akan dapat dirumuskan hipotesis sebagai berikut:

H2 : Kinerja lingkungan semakin menguatkan pengaruh terhadap kinerja keuangan perusahaan.

\section{Metodologi Penelitian}

Penelitian ini dilakukan pada Bursa Efek Indonesia (BEI) dengan tipe penjelasan atau exsplanatory research. Penelitian jenis ini bertujuan menjelaskan hubungan kausal antara variabel-variabel melalui pengujian hipotesis yang telah dirumuskan sebelumnya.Data yang digunakan dalam penelitian ini adalah data sekunder yaitu berupa laporan keuangan tahunan perusahaan. Populasi penelitian ini adalah perusahaan manufaktur sektor industri barang konsumsi di Indonesia yang terdaftar di BEI. Sampel yang digunakan yaitu perusahaan manufaktur sektor industri barang konsumsi yang mempublikasikan laporan keuangan tahunan periode 2015-2017. Pengambilan sampel dalam penelitian ini menggunakan teknik purposive 
sampling. Yaitu metode pengambilan sampel yang didasarkan pada kriteria khusus yang terdapat di dalam populasi. Kriteria yang digunakan adalah sebagai berikut:

1. Perusahaan manufaktur sektor industri barang konsumsi di Indonesia yang menerbitkan laporan keuangan lengkap dari tahun 2015-2017.

2. Perusahaan manufaktur sektor industri barang konsumsi yang menyajikan laporan tanggung jawab sosial dari tahun 2015-2017 yang terdapat pada annual reports perusahaan.

3. Perusahaan manufaktur sektor industri barang konsumsi yang masuk peringkat PROPER.

Variabel independen dalam penelitian ini adalah corporate social responsibility. Perhitungan tanggung jawab sosial yang dilakukan dalam penelitian ini menggunakan standar pengukuran GRI. Setiap pengungkapan perusahaan terhadap tanggung jawab sosial diberi skor 1 untuk informasi yang tersedia sedangkan yang tidak mengungkapkan item tanggung jawab sosial diberi skor 0. Selanjutnya total skor dibagi jumlah item pengungkapan

$$
\text { CSRI }=\frac{\text { Total } X}{n}
$$

\section{CSRI : Corporate Social Responsibility Disclosure Index perusahaan}

Total X : jumlah item yang diungkapkan

n : jumlah item pengungkapan

Variabel dependen merupakan variabel yang dipengaruhi atau menjadi akibat, karena adanya variabel Independen. Variabel dependen dalam penelitian ini kinerja keuangan perusahaan. Kinerja keuangan perusahaan diukur dengan menggunakan rasio profitabilitas yaitu ROA. Rasio ini digunakan untuk mengukur efektivitas perusahaan dalam mengelola asetnya untuk menciptakan laba. Rumus untuk mengukur variabel ini yaitu :

$$
R O A=\frac{\text { Net Income }}{\text { Total Asset }} X 100 \%
$$

Variabel intervening dalam penelitian ini adalah kinerja lingkungan yang diukur menggunakan peringkat perusahaan berdasarkan program PROPER yang diselenggarakan Kementerian Lingkungan Hidup (KLH) dan dinilai menurut warna yang menjadi tolok ukur prestasi suatu perusahaan, yaitu :

Emas : skor 5

Hijau : skor 4

Biru : skor 3

Merah : skor 2

Hitam : skor 1

Metode yang digunakan dalam penelitian ini adalah metode dokumentasi, yaitu mempelajari catatan-catatan perusahaan yang diperlukan yang terdapat didalam laporan tahunan yang menjadi sampel dalam penelitian ini seperti, informasi CSR, ROA dan data lain yang diperlukan. Laporan tahunan tersebut diperoleh melalui situs BEI di www.idx.co.id,selain itu metode pengumpulan juga menggunakan studi pustaka yaitu dengan cara mengumpulkan data dengan membaca buku atau bahan-bahan yang berhubungan dengan masalah yang dibahas dalam penelitian ini. Analisis data dilakukan melalui analisis deskriptif dan uji asumsi klasik.

\section{Hasil}


Penelitian dilakukan pada perusahaan manufaktur sektor industri barang konsumsi yang terdaftar di Bursa Efek Indonesia tahun 2015-2017. Penentuan sampel dapat pada tabel 1.

\section{Tabel 1 Hasil Penentuan Sampel}

\begin{tabular}{clc}
\hline No. & \multicolumn{1}{c}{ Keterangan } & Jumlah \\
\hline 1. & $\begin{array}{l}\text { Perusahaan manufaktur sektor industri barang konsumsi di BEI tahun 2015- } \\
2017\end{array}$ & 42 \\
\hline 2. & $\begin{array}{l}\text { Perusahaan manufaktur sektor industri barang konsumsi yang menyajikan } \\
\text { laporan keuangan lengkap serta laporan tanggung jawab sosial dari tahun } \\
\text { 2015-2017 }\end{array}$ & 42 \\
\hline 3. & $\begin{array}{l}\text { Perusahaan manufaktur sektor industri barang konsumsi yang masuk } \\
\text { peringkat PROPER }\end{array}$ & 13 \\
\hline
\end{tabular}

Berikut merupakan daftar perusahaan manufaktur sektor industri barang konsumsi yang menjadi objek penelitian:

Tabel 2 Daftar Perusahaan yang dianalisis

\begin{tabular}{|c|c|c|}
\hline NO & $\begin{array}{l}\text { KODE } \\
\text { PERUSAHAAN }\end{array}$ & KETERANGAN \\
\hline 1 & ADES & PT Akasha Wira International Tbk \\
\hline 2 & DLTA & PT Delta Djakarta Tbk \\
\hline 3 & GGHM & PT Gudang Garam Tbk \\
\hline 4 & ICBP & PT Indofood CBP Sukses Makmur Tbk \\
\hline 5 & INDF & PT Indofood Sukses Makmur Tbk \\
\hline 6 & KLBF & PT Kalbe Farma Tbk \\
\hline 7 & KAEF & PT Kimia Farma (persero) Tbk \\
\hline 8 & MYOR & PT Mayora Indah Tbk \\
\hline 9 & MERK & PT Merck Indonesia Tbk \\
\hline 10 & MLBI & PT Multi Bintang Indonesia Tbk \\
\hline 11 & SIDO & PT Industri Jamu \& Farmasi Sido Muncul Tbk \\
\hline 12 & ULTJ & PT Ultrajaya Milk Industry and Trading Company Tbk \\
\hline 13 & UNVR & PT Unilever Indonesia Tbk \\
\hline
\end{tabular}

Pengukuran kinerja keuangan perusahaan menggunakan rasio profitabilitas yaitu ROA dengan rumus: Net income dibagi total asset dikalikan 100\%. Setelah melalui perhitungan dengan menggunakan rumus tersebut, kinerja keuangan masing - masing perusahaan tampak pada tabel 3 . 
Tabel 3. Kinerja Keuangan Perusahaan

\begin{tabular}{clrrr}
\hline \multirow{2}{*}{ NO } & \multirow{2}{*}{ Nama Perusahaan } & \multicolumn{3}{c}{ Kinerja Keuangan } \\
\cline { 3 - 5 } & & 2015 & 2016 & 2017 \\
\hline 1 & Akasha Wira & $5,03 \%$ & $7,29 \%$ & $4,55 \%$ \\
\hline 2 & Delta Djakarta & $18,50 \%$ & $21,25 \%$ & $20,87 \%$ \\
\hline 3 & Gudang Garam & $10,16 \%$ & $10,60 \%$ & $11,62 \%$ \\
\hline 4 & Indofood Cbp & $11,01 \%$ & $12,56 \%$ & $11,21 \%$ \\
\hline 5 & Indofood Sukses Makmur & $4,04 \%$ & $6,41 \%$ & $5,85 \%$ \\
\hline 6 & Kalbe Farma & $15,02 \%$ & $15,44 \%$ & $14,76 \%$ \\
\hline 7 & Kimia Farma & $7,82 \%$ & $5,89 \%$ & $5,44 \%$ \\
\hline 8 & Mayora & $11,02 \%$ & $10,75 \%$ & $10,94 \%$ \\
\hline 9 & Merck Indo & $22,22 \%$ & $20,68 \%$ & $17,08 \%$ \\
\hline 10 & Multi Bintang & $23,65 \%$ & $43,17 \%$ & $52,67 \%$ \\
\hline 11 & Sido Muncul & $15,65 \%$ & $16,08 \%$ & $16,90 \%$ \\
\hline 12 & Ultra Jaya & $14,78 \%$ & $16,74 \%$ & $13,72 \%$ \\
\hline 13 & Unilever & $37,20 \%$ & $38,16 \%$ & $37,05 \%$ \\
\hline
\end{tabular}

Kinerja lingkungan masing-masing perusahaan manufaktur sektor industri barang konsumsi digambarkan d tabel 4.

Tabel 4. Perhitungan Kinerja Lingkungan

\begin{tabular}{clccc}
\hline \multirow{2}{*}{ No } & \multirow{2}{*}{ Nama Perusahaan } & \multicolumn{3}{c}{ Proper } \\
\cline { 3 - 5 } & & 2015 & 2016 & 2017 \\
\hline 1 & Akasha Wira & 3 & 2 & 3 \\
\hline 2 & Delta Djakarta & 3 & 3 & 3 \\
\hline 3 & Gudang Garam & 3 & 3 & 3 \\
\hline 4 & Indofood Cbp & 4 & 4 & 3 \\
\hline 5 & Indofood Sukses Makmur & 3 & 3 & 3 \\
\hline 6 & Kalbe Farma & 3 & 3 & 3 \\
\hline 7 & Kimia Farma & 3 & 3 & 3 \\
\hline 8 & Mayora & 2 & 3 & 3 \\
\hline 9 & Merck Indo & 1 & 1 & 3 \\
\hline 10 & Multi Bintang & 3 & 3 & 4 \\
\hline 11 & Sido Muncul & 3 & 4 & 4 \\
\hline 12 & Ultra Jaya & 3 & 3 & 3 \\
\hline 13 & Unilever & 3 & 3 & 3 \\
\hline
\end{tabular}

Variabel intervening pada penelitian ini adalah kinerja lingkungan dengan menggunakan PROPER sebagai alat pengukuran. PROPER dinilai berdasarkan warna yang diperoleh perusahaan yang dijadikan sebagai tolok ukur. Menurut Kementerian Lingkungan Hidup dan Kehutanan, penentuan nilai proper sebagai terdaat di tabel 5. 
Tabel 5 Penilaian Peringkat PROPER

\begin{tabular}{ccc}
\hline No. & Warna & Keterangan \\
\hline Rp1 & Emas & Sangat Memuaskan \\
\hline Rp2 & Hijau & baik \\
\hline Rp3 & Biru & Sesuai standar minimal \\
\hline Rp4 & Merah & Kurang \\
\hline Rp5 & Hitam & $\begin{array}{c}\text { Belum menerapkan } \\
\text { standar }\end{array}$ \\
\hline
\end{tabular}

Sumber : Adiputra, Ginting, Normansyah, Yanuar, and Muliani (2005)

Berdasarkan hasil analisis statistik deskriptif dilakukan untuk memberikan gambaran atau deskripsi suatu data yang dilihat dari nilai rata - rata (mean), standar deviasi, maksimum, minimum dari masing - masing variabel (Ghozali, 2005). Berdasarkan perhitungan melalui SPSS tampak hasil analisis statistik deskriptif terdapat di tabel 6.

Tabel 6 Hasil analisis statistik deskriptif

\begin{tabular}{|c|c|c|c|c|c|c|}
\hline & $\mathrm{N}$ & & Min & Max & Mean & $\begin{array}{l}\text { Std. } \\
\text { Deviation }\end{array}$ \\
\hline CSR & & 39 & 0,11 & 0,31 & 0,17 & 0,04 \\
\hline Proper & & 39 & 0,00 & 4,00 & 2,67 & 0,93 \\
\hline ROA & & 39 & 0,04 & 0,53 & 0,17 & 0,11 \\
\hline $\begin{array}{l}\text { Valid N } \\
\text { (listwise) }\end{array}$ & & 39 & & & & \\
\hline
\end{tabular}

Hasil deskripsi variabel penelitian melalui statistik deskriptif diketahui bahwa dari 39 data amatan selama tiga tahun yaitu tahun 2015, 2016, dan 2017 dengan jumlah sampel 13 perusahaan. PT Gudang Garam TBK memiliki tingkat pengungkapan CSR yang rendah, sedangkan PT Indofood sukses makmur tbk memperoleh nilai maksimum. Dan dari hasil pengujian statistik deskriptif sebesar $16,73 \%$ telah mengungkapkan CSR sesuai kriteria yang ditetapkan, dengan demikian dapat dikatakan bahwa selama tiga tahun ini, perusahaan yang menjadi sampel telah melakukan pengungkapan CSR yaitu sebanyak 16,73\% dengan nilai standar deviasi sebesar 0.0425. Selain itu berdasarkan uji statistik tersebut dapat dikatakan bahwa perusahaan masih belum mengungkapkan CSR nya secara penuh.

Untuk variabel kinerja lingkungan yang dinilai dengan menggunakan PROPER. Nilai minimum kinerja lingkungan sebesar 0 dilakukan oleh PT Merck Indo Tbk pada tahun 20152016. Sedangkan nilai maksimumnya sebesar 4. Berdasarkan statistik pada tabel 4.7 diatas menunjukkan bahwa rata - rata sebesar 2,67 atau sekitar 267\% dengan standar deviasi sebesar 0,927. Dapat dikatakan perusahaan yang menjadi sampel dalam penelitian ini mendapat peringkat PROPER yang sudah baik.

Berdasarkan tabel 7, tampak pula penilaian kinerja dengan menggunakan ROA nilai kinerja keuangan minimum sebesar 0,0404 atau 4\% diperoleh PT Indofood Sukses Makmur tahun 2015. Sedangkan nilai maksimum sebesar 0,5267 atau sekitar 52\% diperoleh PT Multi Bintang Tbk tahun 2017. Rata - rata kinerja keuangan sebesar 0,165 atau sebesar $16 \%$ dengan standar deviasi sebesar 0,1125 hal ini membuktikan bahwa $16 \%$ perusahaan mampu menghasilkan laba bersih dari total aset yang dimiliki. 
Selanjutnya berdasarkan hasil uji asumsi klasik dengan menggunakan uji normalitas, multikolinearitas, heteroskedastisitas dan autokorelasi menunjukkan hasil sebagai berikut.

1. Berdasarkan uji normalitas dengan menggunakan grafik histogram dan Normal Probability Plot, terdeteksi bahwa data terdistribusi normal. Uji normalitas ini juga dilakukan dengan menggunakan Kolmogorov - Smirnov seperti yang memperlihatkan besarnya asymp. Sig.sebesar 0,198 yang berarti signifikansi 0,019>0,05. Dengan demikian dapat disimpulkan bahwa nilai seluruh variabel dinyatakan memenuhi asumsi normalitas.

2. Uji heteroskedastisitas

Pengujian dilakukan dengan melihat grafik plot antara nilai prediksi variabel terikat (dependen) yaitu Standardized Predicted Value (ZPRED) dengan residual Studentized Residual (SRESID). Hasil grafik plot menunjukkan bahwa tidak terdapat pola yang jelas, serta titik - titik menyebar secara acak baik di atas maupun di bawah angka 0 pada sumbu Y, sehingga dapat disimpulkan bahwa dari seluruh hasil pengujian tidak terjadi heteroskedastisitas pada model regresi ini.

3. Uji Multikolinieritas

Variabel CSR dan variabel kinerja lingkungan yang diproksi menggunakan PROPER mempunyai nilai VIF sebesar 1,015 dan tolerance 0,985 . Masing - masing variabel tersebut mempunyai nilai VIF $<10$ dan nilai tolerance $>0,10$ sehingga dapat disimpulkan bahwa tidak terjadi multikolinieritas antara variabel bebas.

4. Uji Autokorelasi

Berdasarkan hasil pengujian autokorelasi tampak bahwa nilai analisis Durbin-Watson sebesar 2,079. Berdasarkan tabel Durbin-Watson dengan signifikansi 0,05 dengan jumlah (n) 29, menghasilkan nilai dL sebesar 0,61624 dan dU 1,26074 sehingga didapat $\mathrm{du}<\mathrm{dw}<4$-du yaitu $1,26074<2,079<2,73926$. Maka dapat disimpulkan model regresi ini tidak terjadi autokorelasi.

Selanjutnya dilakukan pengujian terhadap model dan hipotesis.

Hipotesis pertama pada penelitian ini menyatakan bahwa CSR berpengaruh terhadap kinerja keuangan yang diproksi dengan menggunakan ROA. Dari hasil pengujian tersebut diperoleh t hitung yang lebih besar dari t tabel yaitu 2,907 > 2,0809, dengan nilai signifikan sebesar 0,006 lebih kecil dari tingkat signifikan $\alpha=5 \%$ atau $p$-value $0,006<0,05$. Dengan demikian H1 diterima atau Corporate Social Responsibility berpengaruh secara signifikan terhadap kinerja keuangan perusahaan.

Hipotesis kedua dalam penelitian ini menyatakan bahwa kinerja lingkungan berpengaruh terhadap kinerja keuangan perusahaan. Dari hasil pengujian tersebut diperoleh t hitung yang lebih besar dari t tabel yaitu 4,561>2,0809, dengan nilai signifikan sebesar 0,000 lebih kecil dari tingkat signifikan $\alpha=5 \%$ atau p-value $0,000<0,05$. Dengan demikian $\mathrm{H} 2$ diterima atau hasil tersebut menunjukkan bahwa kinerja lingkungan berpengaruh secara signifikan terhadap kinerja keuangan perusahaan.

\section{Diskusi}

Berdasarkan pengujian hipotesis yang telah dilakukan menunjukkan hasil bahwa CSR berpengaruh secara signifikan terhadap kinerja keuangan perusahaan. Hasil penelitian ini sesuai dengan yang dilakukan oleh Bhernadha et al. (2017) yang menyatakan bahwa CSR berpengaruh terhadap kinerja keuangan. Hal ini sesuai juga dengan teori stakeholder dimana perusahaan tidak hanya bertanggung jawab terhadap pemilik saja (shareholder) namun juga mementingkan faktor - faktor sosial terhadap stakeholder. Hasil tersebut juga menunjukkan bahwa CSR mempengaruhi peningkatan kinerja keuangan, karena informasi CSR yang 
diberikan oleh perusahaan dapat menjadi daya tarik bagi para investor dalam menanam saham pada perusahaan.Perusahaan yang melakukan pengungkapan CSR juga semakin menjaga citra baik khususnya dalam lingkup lingkungan dan sosial.

Berdasarkan pengujian hipotesis yang telah dilakukan menunjukkan hasil bahwa kinerja lingkungan berpengaruh secara signifikan terhadap kinerja keuangan perusahaan. Hasil penelitian yang dilakukan oleh Setyono (2016) menyatakan bahwa secara simultan kinerja lingkungan memiliki pengaruh terhadap kinerja keuangan perusahaan. Hal ini menunjukkan bahwa kinerja lingkungan yang diproksi dengan menggunakan PROPER mendorong perusahaan untuk selalu meningkatkan kinerja dalam pengelolaan lingkungan. Perusahaan perusahaan yang telah memperoleh peringkat dalam program PROPER yang diselenggarakan oleh kementerian lingkungan hidup akan mendapatkan apresiasi yang lebih dari para stakeholder, sehingga akan lebih menarik investor dalam berinvestasi.

\section{Kesimpulan}

Penelitian ini bertujuan untuk mengetahui pengaruh pengungkapan CSR terhadap kinerja keuangan dengan kinerja lingkungan sebagai variabel intervening. Variabel CSR dihitung dengan menggunakan indeks CSR. Untuk variabel kinerja keuangan diproksi dengan menggunakan ROA, sedangkan kinerja lingkungan menggunakan proksi PROPER yang diselenggarakan oleh kementerian lingkungan hidup. Periode pengamatan dalam penelitian ini yaitu selama tiga tahun mulai 2015-2017. Jumlah sampel yang digunakan sebanyak 13 perusahaan manufaktur sektor industri barang konsumsi yang terdaftar di Bursa Efek Indonesia yang telah dipilih berdasarkan kriteria - kriteria tertentu. Hasil yang diperoleh dari kajian ini adalah,

- CSR berpengaruh secara signifikan terhadap kinerja keuangan perusahaan. Hal ini didukung dengan hasil pengujian yang menunjukkan bahwa $\mathrm{t}$ - hitung lebih besar dari $\mathrm{t}$ - tabel, yaitu 2,907 > 2,0809 dengan nilai signifikansi kurang dari 0,05 yaitu $\mathrm{p}$ - value $0,006<0,05$.

- Kinerja lingkungan sebagai variabel intervening berpengaruh secara signifikan terhadap kinerja keuangan perusahaan. Hal ini didukung dengan hasil pengujian yang menunjukkan bahwa $\mathrm{t}$ - hitung lebih besar dari $\mathrm{t}$ - tabel, yaitu 4,561 > 2,0809 dengan nilai signifikansi kurang dari 0,05 yaitu $\mathrm{p}$ - value $0,000<0,05$.

\section{Daftar Pustaka}

Adiputra, I. K., Ginting, S., Normansyah, A., Yanuar, H., \& Muliani, H. (2005). Sekilas Proper Dulu, sekarang, dan Masa Mendatang

Bhernadha, Y. A., Topowijono, \& Azizah, D. F. (2017). Pengaruh Corporate Social Responsibility Terhadap Kinerja Keuangan Perusahaan. Jurnal Administrasi Bisnis, Volume 44(Nomor 1).

Candrayanthi, A. A. A., \& Saputra, I. D. G. D. (2013). Pengungkapan Corporate Social responsibilty Terhadap Kinerja Perusahaan. journal Akuntansi, Volume 4(Nomor 1), 142.

DJ, A. M., Artini, L. G. S., \& Suarjaya, A. A. G. (2012). Pengaruh Kinerja Keuangan Terhadap Nilai Perusahaan Pada Perusahaan Manufaktur Di bursa Efek Indonesia. journal manajemen, Volume 6(Nomor 2), 131.

fitriani, A. (2013). Pengaruh Kinerja Lingkungan Dan Biaya Lingkungan Terhadap Kinerja Keuangan Pada BUMN journal Ilmu Manajemen, Volume 1(Nomor 1), 139. 
Gantino, R. (2016). Pengaruh Corporate Social Responsibility Terhadap Kinerja Keuangan Perusahaan Manufaktur yang Terdaftar di Bursa Efek Indonesia. journal Dinamika Akuntansi Dan Bisnis Volume 3(Nomor 6), 21.

Ghozali, I. (2005). Aplikasi Analisis Multivariate Dengan Program SPSS: Badan Penerbit Universitas Diponegoro.

Ibrahim, M., Solikahan, E. Z., \& Widyatama, A. (2015). Karakteristik Perusahaan, Luas Pengungkapan Corporate Social Responsibility, Dan Nilai Perusahaan. Jurnal Akuntansi, Volume 6(Nomor 1), 99-106.

Lako, P. D. A. (2011). Dekonstruksi CSR dan Reformasi Paradigma Bisnis dan Akuntansi: Penerbit Erlangga.

Parengkuan, W. E. (2017). Pengaruh Corporate Social Responsibility Terhadap Kinerja Keuangan Perusahaan Manufaktur. Jurna EMBA, Volume 5(Nomor 2).

Pratiwi, R. (2012). Pengaruh Tingkat Pengungkapan Tanggung Jawab Sosial Dan Corporate Social Responsibility Dengan Kinerja Keuangan Perusahaan. Jurnal Ilmiah STIE MDP, Volume 2(Nomor 1).

Purwanto, A. (2011). Pengaruh Tipe Industri, Ukuran Perusahaan, Profitabilitas, Terhadap Corporate Social responsibility. journal Akuntansi Dan Auditing, Volume 8(Nomor 1), 14.

Rahmah, P. A. A. A., \& Iramani, R. (2015). Pengaruh Corporate Social Responsibility Pada Kinerja Keuangan Perusahaan Pertambangan. Jurnal Business and Banking, Volume 5(Nomor 2).

Rosiana, G. A. M. E., Juliarsa, G., \& Maria M, R. S. (2013). Pengaruh Pengungkapan CSR Terhadap Nilai perusahaan Dengan Profitabilitas Sebagai Variabel Pemoderasi. Jurnal akuntansi, Volume 5(Nomor 3), 725.

Setyono, J. (2016). Pengaruh Kebijakan Sosial dan Kinerja Lingkungan Terhadap Kinerja Keuangan Perusahaan Manufaktur Go Public di Bursa Efek Indonesia. Jurnal Business and Banking, Volume 5(Nomor 2).

Tjahjono, M. E. S. (2013). Pengaruh Kinerja Lingkungan Terhadap Nilai Perusahaan Dan Kinerja Keuangan. journal Ekonomi, Volume 4(Nomor 1), 38. 